\section{From hope to crisis and back again? A critical history of the global CBNRM narrative}

\author{
WOLFRAM DRESSLER ${ }^{1 *}$, BRAM BÜSCHER ${ }^{2,3}$, MICHAEL SCHOON $^{4}$, \\ DAN BROCKINGTON ${ }^{5}$, TANYA HAYES ${ }^{6}$, CHRISTIAN A. KULL ${ }^{7}$, \\ JAMES MCCARTHY ${ }^{8}$ AND KRISHNA SHRESTHA ${ }^{9}$ \\ ${ }^{1}$ School of Social Sciences, University of Queensland, Australia ${ }^{2}$ Institute of Social Studies, Erasmus University \\ Rotterdam, the Netherlands ${ }^{3}$ Department of Geography, Environmental Management E Energy Studies, \\ University of Johannesburg, South Africa ${ }^{4}$ Center for the Study of Institutional Diversity, Arizona State \\ University, USA ${ }^{5}$ Institute for Development Management and Policy, University of Manchester, Manchester, UK \\ ${ }^{6}$ Institute for Public Service, Seattle University, Seattle, WA, USA ${ }^{7}$ School of Geography and Environmental \\ Science, Monash University, Melbourne, Australia ${ }^{8}$ Department of Geography, Pennsylvania State University, \\ USA, and ${ }^{9}$ Faculty of Architecture, Design and Planning, University of Sydney, Sydney, Australia \\ Date submitted: 2 September 2009; Date accepted: 18 December 2009; \\ First published online: 14 June 2010
}

THEMATIC SECTION

Community-based natural resource management (CBNRM): designing the next generation (Part 1)

\section{SUMMARY}

Community-based natural resource management (CBNRM) has been on the ascendancy for several decades and plays a leading role in conservation strategies worldwide. Arriving out of a desire to rectify the human costs associated with coercive conservation, CBNRM sought to return the stewardship of biodiversity and natural resources to local communities through participation, empowerment and decentralization. Today, however, scholars and practitioners suggest that CBNRM is experiencing a crisis of identity and purpose, with even the most positive examples experiencing only fleeting success due to major deficiencies. Six case studies from around the world offer a history of how and why the global CBNRM narrative has unfolded over time and space. While CBNRM emerged with promise and hope, it often ended in less than ideal outcomes when institutionalized and reconfigured in design and practice. Nevertheless, despite the current crisis, there is scope for refocusing on the original ideals of CBNRM: ensuring social justice, material well-being and environmental integrity.

Keymords: biodiversity conservation, CBNRM, neoliberalism, social justice

\section{INTRODUCTION}

The end of the Second World War saw international donors and states intensify and extend centralized approaches to conservation and development in much of the developing world. In the context of modernization and the growth of donor aid in the 1960s, developing states retained support

\footnotetext{
*Correspondence: Dr Wolfram Dressler

e-mail: w.dressler@uq.edu.au
}

for strong conservation measures, often for the benefit of elites, tourism and conservation goals (Neumann 2001, 2004). The morality and efficacy of coercive conservation was questioned by conservationists, who realized that restrictions could be harmful to local social and material well-being, thus fuelling individual and collective resistance which undermined conservation objectives (West \& Brechin 1991; Brandon \& Wells 1992). In line with the rise of social movements and ideas around a fairer international economic order in the 1970s, conservation initiatives drew on notions of participatory engagement, indigenous knowledge and community needs in pursuit of combined objectives involving social justice, poverty reduction and biodiversity conservation (Brokensha et al. 1980; Chambers 1983; Fals-Borda 1987).

Increasingly, managers argued that because local people already used, relied on and managed natural resources, they were in the best position to conserve them with external assistance. Placing emphasis on how local peoples' abilities and knowledge could be tapped to make conservation empowering and culturally compatible, new grass roots approaches variously called integrated conservation and development projects (ICDPs), community-based conservation (CBC) and community-based natural resources management (CBNRM) came to challenge previous practices (Berkes 1989; Marcus 2001; Campbell \& Vainio-Mattila 2003). There were hopes that this change in paradigm would bring about more locally relevant and equitable forms of conservation (Kellert et al. 2000; Berkes 2004). Initially then, CBNRM was conceived of as an incremental social process of assisting impoverished communities to set priorities and make decisions for developing natural assets and social equality to reduce livelihood vulnerability and improve conservation (Berkes 1989; Western \& Wright 1994; Horowitz 1998; Berkes 2004). Yet, it was in this broader definition that conservationist ideologies and motives were often found to contradict rural ways of life across the globe.

Almost three decades later, the ideal of CBNRM finds itself caught up in complex administrative and policy structures 
(Blaikie 2006), perversely hybridized with wider neoliberal restructuring (McCarthy 2005) and challenged by a resurgent protectionist conservation (Soule \& Lease 1995; Hutton et al. 2005). Today, CBNRM is experiencing a crisis of identity and purpose, with even the most positive examples experiencing only fleeting success due to major deficiencies. We draw on six case studies from around the world to offer a critical history of how and why the global CBNRM narrative has unfolded over time and space. This is important because, while CBNRM may be treated as a technical problem-solving exercise, namely 'how to conserve wildlife/habitat in rural landscapes', it must also be analysed critically in order to understand what happens to these well-laid plans and good intentions. For all the idealism inherent in CBNRM, it is never actually ideal in practice. When CBNRM is worked out on the ground it must deal with various forces, movements and dynamics which can turn it into something quite different from what its architects imagined. However, despite CBNRM's current crisis of legitimacy, there remains considerable potential for refocusing the approach toward its core objectives: social justice, material well-being and environmental integrity.

We have three aims in this paper: (1) to identify the origins and outcomes of CBNRM around the globe, (2) to demonstrate that while CBNRM ideals were never absolute, primary objectives have been compromised over time and (3) to argue that the initial hope of CBNRM producing equitable solutions for poverty reduction and conservation can be regained with renewed emphasis on integrating social justice with conservation. We conclude that this will require placing greater emphasis on the need for more multi-level critical analysis of CBNRM that identifies false beliefs and practices embedded in the concept, as well as opens up avenues to restore hope.

\section{CBNRM AND ITS DISCONTENTS}

Our historical overview of CBNRM builds on two frameworks. First, we draw on Quarles van Ufford et al.'s (2003) analysis of three general phases or disjunctures in the postwar history of development: hope, politics/administration and critical understanding. Hope refers to the initial hope embedded in new ideas for the future; in the case of CBNRM, the possibilities for a better integration between human needs and biodiversity conservation. Politics and administration relate to the process when ideals become caught up with organizational forms and relationships that devise technologies for their implementation. Critical understanding comes down to viewing development as a domain of knowledge production and diffusion, as well as a site of particular knowledge constructions about how the world works (Lewis \& Mosse 2006). The point is to both recognize and account for the inconsistencies between the various disjunctures and faces of CBNRM while also trying to bridge critical reflections with the dynamics of practical local solutions.

Second, we draw on Brosius et al.'s (2005) suggestion that, while the moral obligation to act may still be a part of CBNRM, motives and actions also become reconfigured as they are mired in bureaucracies with competing political interests and management priorities. In this sense, the moral justification to act through CBNRM and its contrasting objectives become entangled through the processes of their own implementation by governments, non-governmental organization (NGO) administrations and local actors. Increasingly, the ways in which CBNRM is 'formed, promoted and institutionalized' arises through various levels of influence that consist of different values, understandings and motives that span the local and international level (Brosius et al. 1998, p. 160; see also Brosius 1999). The following section chronicles the significant roots, institutional structures and political processes that have forged the policies and practices of CBNRM through both local specificities and global structural dynamics.

\section{Coercing conservation}

The origins of CBNRM are best understood in relation to the history of the western conservation model. From 18th century and onwards, ideals of a people-free landscape for the purposes of leisure and consumption played an important role in defining land use in colonized regions of the world (Neumann 2002; Brockington et al. 2008). While many reserves preceded Yellowstone as America's first national park in 1872 (Cronon 1995; Brockington et al. 2008), the Park's management approach of restricting local access to natural resources through coercion became the de facto model for most protected areas (Nash 1967; Stevens 1997; Igoe 2005). In the post-war period, as the conservation movement began to diversify (through capitalist expansion) in ways that would later support the rise (and fall) of CBNRM, so-called 'fortress conservation' strongly influenced the development of protected areas in former colonies (Neumann 1998). Conservation policies upheld the view that those who depended on resources near reserves be criminalized for what they harvested, and, where identity was closely tied to livelihoods, for who they were (Neumann 1998). In some cases, resource dependent peoples were forcibly removed and dispossessed from lands, else suffering economic displacement (Brechin et al. 2002; Brockington \& Igoe 2006; Dowie 2009). The 'legitimacy' of Anglo-European scientific understandings of nature and culture were reproduced coercively through protected areas for decades (Brockington et al. 2008).

\section{Historical shifts to CBNRM}

In this context of inequality and human suffering, resistance and political struggle grew rapidly. In the 1960s, social movements, networks and programmes with emancipatory objectives grew in strength, pressing the conservation agencies of independent states to care for their citizens' livelihoods through more inclusive approaches (Hutton et al. 2005). Critical scholars working on participatory approaches and conservation with indigenous peoples argued that conservation ultimately silenced those people who held the greatest insights into their own state of affairs in the name of science (Simpson 2001; Ryan \& Robinson 1990). The 
ideology of participatory research, community development and grass roots conservation soon converged to advocate that marginalized peoples harness their own experiences and knowledge to define priorities and enhance their capacities for action (Hall 1981; Ryan \& Robinson 1990).

In the $1970 \mathrm{~s}-1980 \mathrm{~s}$, the drive of grass roots initiatives soon pressed for community-based solutions to larger environmental problems (Brokensha et al. 1980; Chambers 1983). The early environmental movement, powerful publications such as Silent Spring (Carson 1962), innovative academic work (Berkes 1989) and international policy documents (such as Our Common Future; WCED [United Nations World Commission on Environment and Development] 1987) all emphasized the need 'to seek a new balance in the use of both 'scientific' and 'traditional management systems' (Berkes 1989, p. 3). Academics and practitioners now emphasized that because local people already used, relied on and managed natural resources, they were most suited to conserve them, though with extra-local support. They set out to work with local resource users and traditional management in common property systems to ensure conservation met local livelihood aspirations and scientific objectives (Ostrom 1990; Western \& Wright 1994). NGOs and park managers adopted 'devolved', 'collective' and/or 'community-based' natural resource management by facilitating and building on local interests and management capabilities to assist local people to make decisions and develop resources in order to support livelihood and conservation (Western \& Wright 1994; Wittayapak \& Dearden 1999; Li 2002; Berkes 2004). The CBNRM agenda had been set.

The 1980s-1990s saw the scaling up, institutionalizing and merging of community and conservation concerns in a political-administrative framework that some consider a 'global biodiversity conservation regime' (for example, in 1992, the World Summit on Sustainable Development) (Escobar 1998). The popularity of 'sustainable development' led to a rash of poorly conceived and rarely successful, largescale 'integrated conservation and development projects' (Brandon \& Wells 1992). In parallel, CBNRM practitioners sought to 'make nature and natural products meaningful to rural communities' through markets in contrast to local people seeing CBNRM as the means by which to regain control over natural resources for livelihood security and conservation (Western \& Wright 1994). CBNRM fostered intense relationships between local communities, conservationists and donors, thereby creating and institutionalizing major political disjunctures in the intent and ideal of CBNRM. The outcomes of this process have led to the current CBNRM predicament.

\section{THE SHIFTING GROUND OF CBNRM AT THE LOCAL-GLOBAL SCALE}

In line with our first aim, we now identify the origins and outcomes of CBNRM in different regions of the world. Drawing on the conceptual framework above, we also address our second aim of showing how the initial hope of CBNRM generating equitable solutions to poverty reduction and conservation has become compromised by institutional and bureaucratic reconfigurations. We highlight the philosophies, programme designs and local conditions that have driven contrasting outcomes across the globe, east to west.

\section{The rise and fall of CBNRM in the Philippines}

CBNRM in the Philippines arose in response to colonial conservation policy and practice that centred on coercion and injustice, restricting indigenous peoples' use of forest resources. Despite good intentions, the case shows how CBNRM's original objectives of local empowerment for rights to land, livelihood and conservation effectively supported state interests in sedentarized agriculture and market expansion.

Much of the colonial period, from Spanish (1521-1898) to American (1902-1945) rule, involved the zoning of timber resources in protected areas, from which uplanders were evicted as squatters on public lands. Little had changed after independence in 1945, with foresters criminalizing the use of forest resources near park boundaries. In the 1960s and 1970s, Dictator Ferdinand Marcos expanded his timber monopoly into forest frontiers and aimed to sedentarize swidden cultivators with de facto tenure and agroforestry schemes (Vitug 2000; Dressler 2006). In 1986, the masses and civil society revolted, ousting Marcos during the first People Power Revolution, creating communitybased solutions to social injustice and deforestation (Hilhorst 2003). Constitutional recognition of ancestral land rights and devolution then enabled NGOs to push ahead with national anti-logging campaigns, indigenous rights agendas and livelihood programmes. Manila-based campaigns soon targeted the country's environmental hotspots, of which Palawan Island was primary.

Palawan Island's status of ecological frontier went global in the late $1990 \mathrm{~s}$, drawing major NGO and governmentled CBNRM initiatives. But CBNRM on Palawan reflected multiple shades of green. With a celebrity mayor promoting a 'clean and green' political platform, the island's capital, Puerto Princesa City, hosted organizations promoting alternative livelihoods for forest dwellers in order to limit swidden agriculture. Moreover, the buffer zones of the island's flagship World Heritage Site, the Puerto Princesa Subterranean River National Park, hosted local and international NGOs who offered the Tagbanua and Batak (indigenous swidden farmers and hunter-gatherers, respectively) projects that simply reregulated forest use and swidden toward sedentarization with market-based solutions (Dressler 2006).

Several cases show how community-based practitioners sought to intensify and modify Tagbanua and Batak swiddenbased livelihoods in Palawan. In 2007, the NGO, Tagbalay Foundation, set out to develop an extensive nursery with 100 s of seedlings of indigenous fruit trees and hardwoods for planting in swidden fallows. In 2008, in partnership with the City Agriculturist's office, Nestle Incorporated introduced cacao seedlings in new swidden fallows. In 2009, the NGO Haribon Palawan worked through a UNDP programme to implement several hectares of paddy fields for Tagbanua 
to harvest and sell surplus rice in local and city markets, providing them with high-yielding seeds and capital with which to enhance production. In contrast, it was hoped that the Batak would 'voluntarily' adopt agroforestry plots in order to stabilize swiddens with tree crops for sale in markets nearby. These CBNRM projects were designed to have Tagbanua and Batak abandon swidden for paddy rice farming, despite history showing that neither group adopted paddy rice or agroforestry with any great success.

Despite the promise of CBNRM, there are countless examples in the Philippines of well-meaning internationallyfunded programmes being implemented under the assumption that pre-existing subsistence livelihoods need to be sedentarized and modernized. Most of the country's CBNRM programmes and projects have been implemented under the broader assumption of how rural people and livelihoods should be or become over time: productive citizens who embrace modernity. The ability of CBNRM planners to modernize efficiently has arisen through the process of criminalizing, erasing and replacing earlier land uses with commercial agriculture.

\section{Nepalese community forestry: who wins, who loses?}

CBNRM arose in Nepal through forest policies developed and implemented by state forestry agencies. The case demonstrates how well intentioned community-forestry policies and projects did support 'collective' afforestation, but ultimately emboldened local elites politically and financially.

Early forest policies emphasized 'efficient' economic forest management for maximizing revenue, leading to conservation outcomes that disadvantaged minority groups (Shrestha \& McManus 2008). In 1957, state efforts to nationalize private forest holdings ensured most forestlands were under centralized government control. Since the mid-1970s, however, increased pressure for more democratic governance, decentralization and bottom-up planning has emphasized the need to work through pre-existing local panchayats (village councils) to involve local people in forest management. Against this background, the community forestry (CF) policy emerged in 1976 because of the failure to halt deforestation and the need for policies that were responsive to local needs and indigenous resource use. This change represented a paradigm shift from the state-controlled policies to userbased decentralized control policies (Gilmour \& Fisher 1991). Radical as these changes may have been, it remains to be seen whether there was sufficient political will to change a centrist bureaucratic culture and practice toward a locally driven forest management model.

In the case of Nepalese CF, the voluntary labour provided by community groups has significantly improved highly degraded forests (Shrestha \& McManus 2008). Legally, all forest users must follow local management rules which aim to minimize forest use and ensure forest conservation. However, local elites set the rules and, unlike the poor and minorities, they depend less on community forests for their livelihoods. Local elites have few difficulties implementing protection-oriented management approaches for the simple reasons that they are (1) supported by the state forest officials and international donor agencies (DANIDA [Danish International Development Agency], USAID [United States Agency for International Development] and AUSAID [Australian Government Overseas Aid Program]) and (2) that protectionist rules are, in this case, easier to enforce than complex rules regulating the sustainable use of forests (Shrestha \& McManus 2007). This has resulted in the under use of forests and reduced the flow of forest products to the local poor and minorities.

The shift towards CBNRM in Nepal has largely failed to strike a reasonable balance between the conservation of forests and the socioeconomic needs of forest-dependent poor people. This can be attributed to the protection-oriented management practices promoted by state officials and many conservation organizations. The irony is that the poor have been made worse off under CF and lost much of their local autonomy to vested interests.

\section{Madagascar: CBNRM for and by outsiders}

CBNRM initiatives in Madagascar have been pushed and organized by foreigners and a cadre of Malagasy bureaucrats and scientists. CBNRM grew within a complex conservation bureaucracy that largely held the opposing goal: limiting local resource use practices.

Nature conservation in Madagascar builds on the legacy of the French colonial government, which restricted forest clearance and fire-setting by locals, and established the first nature reserves in the 1920s. Conservation efforts in this biodiversity hotspot boomed from the late 1980s, when the World Bank, WWF and various bilateral aid programmes partnered with the Malagasy government to propose a massive National Environmental Action Plan. Implemented 19912008 , the three-phase Plan received almost US\$ 50 million in cumulative funding (Hufty \& Muttenzer 2002; Pollini 2007).

The Plan's second phase, responding to international trends, emphasized community-based resource management. The common property tradition (Berkes 1989; Weber 1995) heavily inspired the approach developed by French, American and Malagasy scholar-practitioners. The resulting 1996 legislation, known as GELOSE (gestion locale sécurisée = secure local management), permits granting of management rights over specific natural resources to community associations. These associations enter into a contract with the local municipality and the relevant government ministry. Implementation of GELOSE requires the creation and registration of community associations, the assessment and delimitation of the resource and the use of a specially trained 'environmental mediator' to negotiate the contracts (Antona et al. 2004). In addition, a problematic and infrequently-used 'relative' land tenure process facilitates zoning the resource involved, but not actual titling (Le Roy et al. 2006). Given this complexity, GELOSE contracts have always been created 
through the initiative and guidance of NGOs and projects, usually foreign-funded.

For some practitioners, GELOSE was too cumbersome. As a result, they developed a simpler alternative, called GCF (gestion contractualisée des forêts $=$ forest management contracts), by decree in 2001 (Montagne \& Ramamonjisoa 2006). Unlike GELOSE, GCF requires neither tenure allocation, mediation, nor negotiation with the municipality. However, it can only be applied to state forest lands, such as reserved or classified forests. At one point, the competing GELOSE and GCF approaches became emblematic of rivalries between different donors and NGOs.

In 2003, spurred by conservationists, President Ravalomanana announced that the country would triple its protected areas in five years. This 'conservation emergency' (Marie et al. 2009), subsequently overrode any meaningful community engagement (Pollini 2007; Corson 2008). Various NGOs continued developing new GCF and GELOSE contracts, but this took place in the spirit of Ravalomanana's ambitious, and not very participatory, programme for high-speed economic development and urgent conservation. Overall, more than 450 local management contracts were established. Evaluations point to both successes and failures. Concerns have been raised over longer-term sustainability, and others point to problems with non-representative community associations, with elites that get control of the resources or with new resource conflicts engendered by the contracts (Montagne et al. 2007; Pollini 2007; Toillier et al. 2008).

The conception and implementation of CBNRM in Madagascar was top-down, driven by well-funded foreign conservation and development agencies and dependent bureaucracies. Rural civil society is weak and the state has little capacity or legitimacy to implement decisions. Consequently, outsiders control the agenda (Duffy 2006). While there is hope that the well-meaning CBNRM experiment will take hold and lead to a trend of communities taking meaningful control of their resources, its dependency on outside intervention leads to pessimism about its sustainability.

\section{CBNRM in Southern Africa: from inspiration to ambiguity}

CBNRM programmes emerged in southern Africa in the early 1980s in response to the strictures of Apartheid and neocolonial governance limiting rural people's civil liberties and rights to natural resources. However, this case shows that the enormous hope vested in CBNRM in the region was paralleled by equally ambiguous outcomes through marketbased structures and political/administrative realities, which ultimately led to its current demise.

In the context of an increasingly isolated South African Apartheid state in the 1980s, tensions between countries in the region ran high and multiple initiatives countering top-down neo-colonial governance and policies developed. In some ways, early CBNRM ran as a counter-hegemonic programme aiming to stimulate local ownership and devolution of decision-making power (Mackenzie 1988). Initial forays began in Zimbabwe in the 1980s through CAMPFIRE (Zimbabwe's Communal Areas Management Programme for Indigenous Resources), with parallel programmes emerging in Namibia, Zambia and Botswana (Marks 2008). These initiatives focused on providing benefits to local communities through a utilitarian approach to wildlife. Individually and collectively, these efforts rose to prominence during the 1990s, exciting many in the global conservation and development community.

While advocates loudly proclaimed their successes, actual results were mixed (Fabricius et al. 2004). CAMPFIRE, the shining star of the CBNRM world, struggled to devolve benefits to local resource users (see Murphree 2004). While some Zimbabwean districts did profit from income at household level, in others local elite reaped the rewards or overall income simply was not enough to provide tangible benefits to local people. Meanwhile, Namibia had some success by focusing on the development of community conservancies, which sought to create ecotourism opportunities in marginal grazing lands. The market-based approach of the conservancies appears to have provided more tangible benefits to local people than the alternatives, in the context of Namibia's low human population, marginal rangelands, high levels of biodiversity and strong ecotourism interest (Barnes \& Macgregor 2002). However, the exceptional nature of the Namibian case is counterbalanced by experiences in Zambia where 'there appears to be little within Zambian wildlife history or current circumstances that support ADMADE's promotional claims to enhance rural welfare while promoting 'sustainable conservation' within the central Luangwa Valley. Rather its practices and approaches appear counterproductive to both objectives' (Marks 2008, p. 3).

In 1994, when South Africa ended Apartheid, the regional CBNRM picture changed rapidly. Initially, it seemed that the conservation community and the newly elected government combined to push for more people-oriented conservation policies and programmes. In some areas, such as the Eastern Cape and Limpopo Provinces, communities managed to use the CBNRM rhetoric to legitimate claims over land. However, CBNRM never emerged in South Africa to the extent of its neighbours. This was partly owing to the prominence of the conservation structures already in place. Built around protected areas, this structure was subjected to land restitution claims after 1994 , in a drive to restore land ownership to previously disadvantaged groups and communities. Yet, despite some successes (Fabricius \& de Wet 2002), including the famous case of the Makuleke community owning the northern part of the Kruger National Park, the old system proved resilient. In early 2009, the South African government announced that, with respect to the Kruger Park, all remaining claims were annulled and other solutions for making communities profit from the Park had to be found.

By the late 1990s, critics identified shortcomings of CBNRM, including problems with benefit sharing, the frequent 
mismatch between the goals of the state and communities, and the weakening of local commonage institutions so vital for CBNRM (see Cocks et al. 2001 for the case of the Masakane community in the Eastern Cape Province). As a result, funding for CBNRM steadily decreased, partly as more money went toward transboundary conservation, but especially in support of market-based mechanisms that sought to support public-private-community schemes. The importance of CBNRM in Southern Africa stems mainly from the influence that it had globally. Its primary success in instilling hope that integrating conservation and development might succeed however, should be balanced by noting that the few successes have been undermined by neoliberalisminduced socioeconomic differentiation.

\section{CBNRM and the BOSAWAS Reserve, Nicaragua: merging common interests?}

The CBNRM process that evolved in Bosawas illustrates how external organizations may play a critical role in ensuring indigenous peoples' land and resource rights when resident land use interests are in conjunction with conservation goals. The case also illustrates that the promotion of resource rights, empowerment and sustained environmental governance requires political, technical and financial support that extends longer than the time frames of many CBNRM projects.

Bosawas International Biosphere Reserve is located in remote northern Nicaragua and is part of a set of protected areas created to conserve remnant regional humid tropical forests. In 1991, newly elected President Chamorro created Bosawas as a nature reserve in order to prevent mining and logging in the region (Stocks 2003). At this time, the civil war had recently ended and politicians, indigenous residents (mainly Miskito and Mayagnas) and colonists were fighting to control resources in the region. During the war, many indigenous peoples in Bosawas were either forced to serve one of the militant groups or removed to camps in Nicaragua and Honduras. When the residents returned to their communities after the war, they found that their homelands were now a forest reserve under government jurisdiction, and colonized by many farmers and ex-combatants (Stocks 1996).

In protest against the reserve and colonization, the indigenous peoples of south-western Bosawas joined forces to create a unified political organization to advocate for their land rights. Shortly thereafter, leaders gained the support of Centro Humboldt (a Managua-based NGO) and The Nature Conservancy (TNC) to help establish their land rights while creating a CBNRM plan for the region. TNC took a unique approach in implementing CBNRM in Bosawas. Rather than beginning with conservation interests, TNC first addressed the concerns of the indigenous residents; namely, securing territorial tenure and preventing settler colonization. The NGOs worked with the indigenous residents to demarcate their territories, create CBNRM plans and ultimately demand formal land rights from the Nicaraguan government (Stocks
2003; Hayes 2007). In 1997, the indigenous residents signed an accord with the colonists creating a de facto communitybased land-use plan for the region and, in 2005, the indigenous residents received legal collective titles to their territories, turning a government reserve into an indigenous reserve.

Given clear territorial demarcation and resource management plans, the indigenous residents have conserved the forests and prevented further colonization in the region (Hayes 2007; Stocks et al. 2007). Residents and leaders express great pride in their ability to defend their territory from colonists and manage their lands. The indigenous peoples' ownership of the process points to a key ingredient in the success of Bosawas: residents believe that the CBNRM system is their own creation. Nonetheless, the role of NGOs in the CBNRM process has proven equally significant.

Analysis of the resource management process in Bosawas points to three lessons and a critical concern for the role of external organizations in implementing CBNRM. The first lesson is the importance of supporting residents' needs rather than structuring the management process around a conservation agenda. In Bosawas, by recognizing the residents' demands, the NGOs gained the residents' trust and facilitated the creation of a set of natural resource management plans that both indigenous residents and the colonists perceived to be legitimate (Hayes 2008). Second, the case highlights the technical, financial and organizational costs involved in rule making, and the role that external agencies may play in covering these costs. The NGOs also provided the technical and financial resources necessary for demarcating the territories, acquiring territorial titles, and training and paying the forest guards.

Finally, the case illustrates the costs involved in rule maintenance. The continued dependency on external assistance points to a critical caveat. CBNRM in Bosawas demands sustained financial, institutional and technical support from extra-local sources. Centro Humboldt continues to play a significant role in the region by providing administrative and institutional support. Their presence also serves as a watchdog to ensure compliance with the land-use rules (Hayes 2008). A concern for the future, however, is if and how support for this governance system will be generated on a sustainable basis.

\section{CBNRM in North America}

CBNRM in North America has often taken the form of community forestry programmes and projects. These programmes spread rapidly throughout North America over the past two decades as part of the global dissemination of community forestry as an alternative to fortress conservation and centralized state control over natural resources. This case shows how, despite much promise, community forestry has also been subject to a litany of complaints including, that its establishment violated the rights of local and indigenous populations, and that it has emphasized primary 
commodity production and export at the expense of social and environmental considerations.

While forms of community forestry are pursued at multiple juridical levels in every country in North America (see for example Baker \& Kusel 2003; Bray et al. 2005; Davis 2008), we focus on community forestry on large state-owned National Forests in the USA and Crown forests in Canada. National and Crown forests represent extensive areas of natural resources directly owned and administered by the state. As such, they have much in common with each other and other areas in world that have turned to CBNRM in response to colonial encounters, competing claims and scientific assumptions of best practice.

Many critics of forest governance in both countries saw community forestry as the basis to recognize and privilege local rights, knowledge and priorities and, by so doing, balance and improve social, economic and environmental performance. Calls for community forestry thus grew in both countries during the 1980s and into the 1990s, with strong and explicit linkages to global trends in community forestry. In both the USA and Canada, proponents of community forestry drew from the growing international discourse on community forestry when they made their cases regarding its potential.

Efforts to implement community forestry on large public forests met very different fates in the two countries. In Canada, new community forest tenure categories emerged within forest management systems, giving control over large areas to different community forestry organizations, with indigenous First Nations, environmentalists, cooperatives, municipal governments and other actors all beginning to operate community forests (see McCarthy 2006; Bullock \& Hanna 2008). In the USA, however, efforts to carve out space for community forests within the National Forest system generated fierce controversy, with most major environmental organizations opposing and successfully blocking the efforts (McCarthy 2005). The controversies were both juridical and substantive. Juridically, opponents argued that community forestry was incompatible with key federal environmental legislation, which demanded strong and consistent environmental standards and federal accountability. The substantive fear behind the opposition was that the devolution and more flexible regulation associated with community forestry would be a Trojan horse for increased corporate access and logging, a fear lent weight by the fact that conservative anti-environmental politicians strongly supported community forestry in the USA in the 1990s. Environmentalists thus gave voice to the critical concern that community forestry was perhaps suspiciously compatible with broader trends in the neoliberalization of governance: it shared a deep scepticism regarding state control, a faith in markets, devolution and voluntary and flexible approaches to regulation, and a strong conviction that civil society, or its communities, were best suited to address any market failures or inequities (see McCarthy 2005; Schroeder 1999).
McCarthy (2006) interpreted this divergent outcome as primarily a matter of scale and timing, reflecting trends in environmental governance. While the critiques of the dominant model of forest governance and use were similar in the USA and Canada, the political momentum for reform peaked at very different times in the two countries and, in each case, the responses reflected the prevailing wisdom of the period. Demands for reform of the National Forest system in the USA peaked during the 1970s, and the reforms instituted as a result reflected that period; all centred on the state and strengthened agencies and regulation, particularly a centralized, federal system of forest governance. Subsequent decades saw environmental politics move increasingly to the arena of the courts and the adversarial strategies they demanded. Environmentalists thus saw community forestry as a direct attack on hard-won environmental reforms of state institutions. In Canada, by contrast, political momentum for reform of forest governance did not peak until the 1990s, by which time the shortcomings of the above approach were fully evident, and neoliberal hegemony with respect to questions of governance had arguably taken hold. Thus, the reforms adopted largely eschewed state-centred approaches, and focused instead on flexible and voluntary approaches, with substantial deference and autonomy for market actors and communities. Moreover, governance of Crown forest occurs mostly at the provincial level, allowing for a more varied institutional landscape.

In sum, the adoption or non-adoption of community forestry often seems to have less to do with the specific content of programmes or governance than with questions of what community forestry would replace and with larger trends in governance.

\section{DISCUSSION: THE CBNRM CRISIS?}

The case studies in this paper clearly show that community members have drawn on CBNRM to create new political openings through which to articulate rights over land and resources. Yet the ability of local people to use these opportunities has varied in different places and regions of the world. CBNRM has partly ensured that resource-dependent people have their relative rights and responsibilities to govern natural resources recognized by neighbours, civil society and the state, while conversely CBNRM has produced devolved approaches that have, by privileging conservation, facilitated community disempowerment and impoverishment. First, in the case of the Bosawas Reserve in Nicaragua, scholars and NGOs worked with indigenous peoples to have them identify needs and concerns as the basis for defining and managing ancestral territory to maintain forests and forestbased livelihoods. These indigenous peoples worked through an organization that enabled them to govern with degrees of political autonomy, articulating their rights to secure tenure to resist settler colonization. However, the Bosawas Reserve case also shows that the interests of TNC and local indigenous peoples may have been aligned because it 
provided the best way for TNC to safeguard biodiversity from colonists. Yet, despite the opportunistic merging of local interests with TNC's protectionist programme, by first starting with local needs rather than conservation priorities, the process and outcomes paralleled the expected results of externally-supported collective decision-making structures (compare with Berkes 1989; Western \& Wright 1994).

Second, a different picture emerges in several of the cases where CBNRM's governance design and delivery has often disempowered the very people it was meant to support. In the South African, Malagasy and Philippine cases, state and NGO-led CBNRM followed foreign ideas and concepts, prioritizing biodiversity conservation and seeking to regulate and regularize locals' resource use. In the Nepal case, while 'voluntary' local action helped restore degraded forests, most CBNRM benefits flowed back to powerful community members. In the Philippines too, state actors have merged environmental discourse with CBNRM in order to prop up political campaigns, secure monies and manage resources according to green political visions. The processes by which CBNRM has been reconfigured further influenced why some indigenous farmers adopted green political discourse to manage their resources on the condition of sustainability. Yet, certain literature also shows how CBNRM can serve as an effective avenue for people to assert rights to lands directly against the growing pressure to conserve biodiversity (Stevens 1997; Igoe 2005). Rather than support communitybased conservation, indigenous peoples have furthered their cause by rearticulating meta-narratives of indigeneity, cultural autonomy and environmentalism through CBNRM (see Conklin \& Graham 1995).

In the literature and our cases, the surge in protectionism has sidelined CBNRM or worked through it to ensure preservation takes precedence over indigenous peoples' demands over natural resources (see Wilshusen et al. 2002; Hutton et al. 2005). Rather than aiming to displace the international CBNRM agenda, neoprotectionists worked further to align devolved conservation with market-oriented solutions (such as cash cropping and intensification). Contrary to popular perception, in the process of integrating marketbased approaches with CBNRM, the tendency for devolved conservation to become hybridized and bureaucratized has grown considerably (Igoe \& Brockington 2007). Indeed, the Southern African and Philippine cases show how CBNRM became aligned with market-based solutions, strengthening rather than weakening the hegemonic interests of the state. In the North American context, environmental activists feared that community forestry initiatives would become compatible with broader trends in the neoliberalization of governance, such that initiatives might become increasingly aligned with neoliberal market orthodoxy. Studies have shown that as CBNRM becomes entangled in and hybridized with (inter)national bureaucracies and neoliberalism, conservation governs local resource-use behaviour in line with commodity markets (McCarthy 2005).
Finally, most cases have shown that reconfiguring and standardizing programme policies and practices leads to interventions that are misaligned with local realities (Mosse 2005; Blaikie 2006). The Madagascar case, in particular, shows how major international donors and bilateral aid programmes promoted CBNRM according to international trends. In line with common property theory, the resulting GELOSE legislation required structured tripartite partnerships between government agencies, municipalities and community actors who were to manage resources through registered community associations. International donors, government and practitioners then advocated for more streamlined and predefined policy prescriptions going under the name of 'forest management contracts', which offered local people formalized limited access to state-claimed forests. With an outside push, local people have begun to take part in CBNRM governance bureaucracies, which set out overly organized, and neither necessarily legitimate nor long-term sustainable, solutions to fluid politically-contested problems.

Some suggest CBNRM has been reconfigured as a predefined policy prescription, which guides planners to identify problems and their solutions before implementation (Blaikie 2006); others suggest that CBNRM serves the pragmatic purpose of achieving conservation efficiently by pre-identifying and framing problems, rather than working through and understanding the origins of local needs and concerns (see Cooke \& Kothari 2001). Drawing on dominant understandings of the ideal relationship between culture and nature (for example traditional and sustainable), practitioners often reproduce these very same ideals and sentiments through CBNRM. In the CBNRM bureaucracy, state and NGOs achieve this by rendering livelihood problems as concrete with pre-assigned solutions that involve greater market integration and intensification (see Pagiola et al. 2005 on payment for ecosystem services). Those charged with community-based design and practice have begun simplifying problems in order to offer clear solutions already aligned with the expert cultures of management bureaucracies. The process by which practitioners identify livelihood problems and solutions has thus become a technical exercise with expected political economic outcomes rather than an exercise in genuine hope for empowerment through conservation (Li 2007; West 2007). Critical scholars now argue that the design and implementation of CBNRM has less to do with the hope of engaging the complex issues of social inequity and sustainability than with measurable, transferable and repeatable outcomes often divorced from local peoples' reality.

CBNRM arose as a powerful ideal with promise only to become a near universal strategy for actors to render otherwise complex problems into manageable solutions. In the process of moving from being a diverse grass roots practice unfolding in specific social and environmental contexts, where funds were low but perspective was clear, to being scaled up as a global pre-packaged solution to local problems, CBNRM's near universality may lead to its demise. Yet this is to be expected. Conceptually harmonious and substantive practices 
almost always lose focus once they are 'adopted, developed, circulated and promoted within specific organizations and beyond them, in global and local circulations' (Brosius et al. 1998 , p. 160). While the moral intent of interventions may remain, motives, actions and hope become reconfigured as they are caught up in bureaucratic entanglements, discourses and local complexities (Quarles van Ufford et al. 2003).

\section{CONCLUSIONS: REGAINING HOPE?}

Can CBNRM move from hope to crisis and back again? Is it possible to stimulate a renewed emphasis on integrating social justice with conservation? While, in principle, there is no reason why actors could not revitalize the hope embedded in the early history of CBNRM, it is also obvious that hope for a better future cannot be separated from the other political and economic dynamics of this same history. An assessment for the future, therefore, can only start from an awareness of historical and contemporary trends, which does not bode well for CBNRM. CBNRM has recently done less to support indigenous rights to land and biodiversity than it has to facilitate interventions which offer livelihood designs that align with free market principles. The process of adding new schemes to improve local conditions opens the floodgates to donor-driven ideals and incentives for livelihood change and economic opportunities rooted in neoliberal capitalist production. CBNRM has thus become partly reconstituted in terms of market-based solutions, adding layers of governance that simply complicate being poor.

The ways in which CBNRM ideals and intent become incorporated and reconfigured through bureaucracies and other institutions will only increase in the near future. This hampers the ability of practitioners to use CBNRM to provide meaningful outcomes for local peoples and the resources upon which they depend. To rekindle the original hope embedded in CBNRM, planners and practitioners should privilege social and environmental justice (such as individual and communal rights) over neoliberal logic. In line with the pragmatism of CBNRM, this means ensuring that social inequity be redressed by identifying ways (with and) for marginal people to access, use and control locally valued natural resources with senses of entitlement and political empowerment that also support conservation (Johnson \& Forsyth 2002). We make this bold assertion because it is only by explicitly restoring these core values of social equity and justice that CBNRM can hope to resist the debilitating forces of bureaucratic intervention, donor-driven ideologies and economic logics that have become so disruptive in case studies around the world.

Our call is much in line with that of the World Conservation Union (IUCN), whose vision is for 'a just world which values and conserves nature'. However, this ideological stance is only realistic if married with a basic political savvy. Strengthening CBNRM's local linkages depends on whether interventions recognize and strategically deal with the wider political economic dynamics that constrain and influence local CBNRM spaces (such as political organization or customary lands). The potential for particular CBNRM schemes to achieve their goals will depend on planners reflecting on how and why they design CBNRM relative to their organizational mandates, state and private sector motives and, more crucially, the needs and concerns of local people in changing environments. Such CBNRM is fluid in design, relative in practice and upheld with degrees of success rather than predesigned absolute outcomes. Degrees of success are achievable when ideas and designs are held relative to varying local conditions, and nested in livelihood practices and ideals, familial relations, tenurial structures, political economy, and strong organizational capacity and support.

We argue therefore that some of the core values of CBNRM be brought back to the fore in both discourse and action: ensuring social justice, supporting material wellbeing and stimulating environmental integrity relative to local conditions and context. The prospect of local people sustaining CBNRM for social justice, livelihood security and conservation needs is centred on how well programmes are embedded in sociocultural relations, politics, resource needs and uses and landscape changes.

\section{References}

Antona, M., Biénabe, E.M., Salles, J.-M., Péchard, G., Aubert, S. \& Ratsimbarison, R. (2004) Rights transfers in Madagascar biodiversity policies: achievements and significance. Environment and Development Economics 9: 825-47.

Baker, M. \& Kusel, J. (2003). Community Forestry in the United States: Learning from the Past, Crafting the Future. Washington, DC, USA: Island Press.

Barnes, J.I. \& Macgregor, J. (2002) Economic efficiency and incentives for change within Namibia's community wildlife use initiatives. World Development 30: 667-681.

Berkes, F. (1989) Common-property Resources. Ecology and Community-Based Sustainable Development. London, UK: Belhaven Press.

Berkes, F. (2004) Rethinking Community-based Conservation. Conservation Biology. 18(3): 621-630

Berkes, F. (2007) Community-based conservation in a globalized world. PNAS 104(39): 15188-15193.

Blaikie, P. (2006) Is small really beautiful? Community-based natural resource management in Malawi and Botswana. World Development 34: 1942-1957.

Brandon, K.E. \& Wells, M. (1992) Planning for people and parks: design dilemmas. World Development 20: 557-70.

Bray, D., Merino-Perez, L. \& Barry, D., eds (2005) The Community Forests of Mexico. Austin, TX, USA: University of Texas Press.

Brechin, S., Wilshusen, P., Fortwangler, C. \& West, P. (2002) Beyond the square wheel: toward a more comprehensive understanding of biodiversity conservation as a social and political process. Society and Natural Resources 15: 41-64.

Brockington, D., Duffy, D. \& Igoe, J. (2008) Nature Unbound. Conservation, Capitalism and the Future of Protected Areas. London, UK: Earthscan.

Brockington, D. \& Igoe, J. (2006) Eviction for conservation. Conservation and Society 4: 424-70. 
Brokensha, D., Warren, D.M. \& Werner, O., eds (1980) African Rural Development: Indigenous Knowledge Systems and Development. Lanham, USA: University Press of America.

Brosius, P. (1999) Analyses and interventions: anthropological engagements with environmentalism. Current Anthropology 40: 277-309.

Brosius, P., Tsing, A, \& Zerner, C. (1998) Representing communities: histories and politics of community-based natural resource management. Society and Natural Resources 11: 157-168.

Brosius, P., Tsing, A. \& Zerner, C. (2005) Communities and Conservation: Histories and Politics of Community-Based Natural Resource Management. New York, NY, USA: Altamira Press.

Bullock, R. \& Hanna, K. (2008) Community forestry: creating or mitigating conflict in British Columbia? Society and Natural Resources 21: 71-85.

Campbell, L. \& Vainio-Mattila,, A. (2003) Participatory development and community-based conservation: opportunities missed for lessons learned? Human Ecology 31: 417-437.

Carson, R. (1962) Silent Spring. Boston, MA, USA: Houghton Mifflin.

Chambers, R. (1983) Rural Development: Putting the Last First. London, UK: Longman.

Cocks, M., Dold, A. \& Grundy, I. (2001) Challenges facing a community structure to implement CBNRM in the Eastern Cape South Africa. African Studies Quarterly 5 [www document]. URL http://web.africa.ufl.edu/asq/v5/v5i3a4.htm

Conklin, B. \& Graham, L. (1995) The shifting middle ground: Amazonian Indians and ecopolitics. American Anthropologist 97: 695-709.

Cooke, B. \& Kothari, U. (2001) Participation: The Nem Tyranny? London, UK: Zed Books.

Corson, C.A. (2008) Mapping the development machine: the US Agency for International Development's biodiversity conservation agenda in Madagascar. Ph.D. dissertation, University of California, Berkeley, CA, USA.

Cronon, W. (1995) The trouble with wilderness; or, getting back to the wrong nature. In: Uncommon Ground: Rethinking the Human Place in Nature, ed. W. Cronon, pp. 69-90. New York, NY, USA: W. W. Norton \& Co.

Davis, E.J. (2008). New promises, new possibilities? Comparing community forestry in Canada and Mexico. BC Journal of Ecosystems and Management 9(2): 11-25.

Dowie, M. (2009) Conservation Refugees. The Hundred-Year Conflict between Global Conservation and Native Peoples. Cambridge, MA, USA: MIT Press.

Dressler, W. (2006) Co-opting conservation: migrant resource control and access to national park management in the Philippine uplands. Development and Change 37: 401-426.

Duffy, R. (2006) Non-governmental organisations and governance states: the impact of transnational environmental management networks in Madagascar. Environmental Politics 15: 731-49.

Escobar, A. (1998) Whose knowledge, whose nature? Biodiversity, conservation, and the political ecology of social movements. Fournal of Political Ecology 5: 53-82.

Fabricius, C. \& de Wet, C. (2002) The influence of forced removals and land restitution on conservation in South Africa. In: Conservation and Mobile Indigenous Peoples. Displacement, Forced Settlement, and Sustainable Development, ed. D. Chatty \& M. Colchester, pp. ?-?. New York, NY, USA: Berghahn Books.

Fabricius, C., Koch, E., Magome, H. \& Turner, S., eds (2004) Rights Resources and Rural Development. Community-based
Natural Resource Management in Southern Africa. London, UK: Earthscan.

Fals-Borda, O. (1987) The application of participatory research in Latin America. International Sociology 2(4): 329-347.

Gilmour, D.A \& Fisher, R.J. (1991) Villagers, Forests and Foresters: The Philosophy, Process and Practice of Community Forestry in Nepal. Kathmandu, Nepal: Sahayogi Press.

Hall, B. (1981) Participatory research, popular knowledge and power: a personal reflection. Convergence: An International fournal of Adult Education 14: 6-19.

Hayes, T.M. (2007) Does tenure matter? A comparative analysis of agricultural expansion in the Mosquitia forest corridor. Human Ecology 35: 733-747.

Hayes, T.M. (2008) The robustness of indigenous common-property systems to frontier expansion: institutional interplay in the Mosquitia. Conservation and Society 6: 117-129.

Hilhorst, D. (2003) The Real World of NGOs: Discourses, Diversity and Development. London, UK \& New York, NY, USA: Zed Books.

Horowitz, L. (1998) Integrating indigenous resource management with wildlife conservation: a case-study of Batang Ai National Park, Sarawak, Malaysia. Human Ecology 26: 371-403.

Hufty, M. \& Muttenzer, F. (2002) Devoted friends: the implementation of the convention on biological diversity in Madagascar. In: Governing Global Biodiversity, ed. P. G. Le Prestre, pp. 285-314. London, UK: Ashgate.

Hutton, J., Adams, W.M. \& Murombedzi, J.C. (2005). Back to the barriers? Changing narratives in biodiversity conservation. Forum for Development Studies 2: 341-370.

Igoe, J. (2005) Global indigenism and Spaceship Earth. Globalization 2(3): 377-390.

Igoe, J. \& Brockington, D. (2007) Neoliberal conservation: a brief introduction. Conservation and Society 5(4): 432-449.

Johnson, C. \& Forsyth, T. (2002) In the eyes of the state: negotiating a rights-based approach to forest conservation in Thailand. World Development 30: 1591-1605.

Kellert, S., Mehta, J., Ebbin, S. \& Lichtenfeld, L. (2000) Community natural resources management: promise, rhetoric and reality. Society and Natural Resources 13: 705-715.

Le Roy, E., Bertrand, A. \& Montagne, P. (2006) Gestion locale des ressources renouvelables et sécurisation foncière à Madagascar. In : L'Etat et la gestion locale durable des forêts en Afrique francophone et à Madagascar, ed. A. Bertrand, P. Montagne \& A. Karsenty, pp. 368-96. Paris, France: L'Harmattan.

Lewis, D. \& Mosse, D. (2006) Encountering order and disjuncture: contemporary anthropological perspectives on the organization of development. Oxford Development Studies 34: 1-13.

Li, T. (2002) Engaging simplifications: community based resource management, market processes and state agendas in upland Southeast Asia. World Development 30(2): 265-283.

Li, T. (2007) The Will to Improve: Governmentality, Development, and the Practice of Politics. Durham, NC, USA: Duke University Press.

MacKenzie, J.M. (1988) The Empire of Nature. Hunting, Conservation and British Imperialism. Manchester, UK: Manchester University Press.

Marcus, R. (2001) Seeing the forest for the trees: integrated conservation and development projects and local perceptions of conservation in Madagascar. Human Ecology 29: 381-397.

Marie, C.N., Sibelet, N., Dulcire, M., Rafalimaro, M., Danthu, P. \& Carrière, S. (2009) Taking into account local practices and 
indigenous knowledge in an emergency conservation context in Madagascar. Biodiversity Conservation 18: 2759-2777.

Marks, S. (2008) On the ground and in the villages: a cacophony of voices assessing a 'community-based' wildlife program after 18 years. Munyamadzi Game Management Area Central Luangwa Valley Zambia. Unpublished Report for Mipashi Associates. Sand County Foundation/Bradley Fund for the Environment.

McCarthy, J. (2005) Devolution in the woods: community forestry as hybrid neoliberalism. Environment and Planning A 37: 991014 .

McCarthy, J. (2006) Neoliberalism and the politics of alternatives: community forestry in British Columbia and the United States. Annals of the Association of American Geographers 96: 84104.

Montagne, P. \& Ramamonjisoa, B. (2006) Politiques forestières à Madagascar: entre répression et autonomie des acteurs. Économie Rurale 294-295: 9-26.

Montagne, P., Razanamaharo, Z. \& Cooke, A., eds (2007) Le Transfert de Gestion à Madagascar; dix ans d'efforts: Tanteza. Montpellier, France: CIRAD.

Mosse, D. (2005) Cultivating Development. An Ethnography of Aid Policy and Practice. London, UK: Pluto Press.

Murphree, M. (2004) Resource management in Africa: from whence to where? Keynote address to Breslauer Graduate Student Symposium, Berkeley, California, 5 March 2004 [www document]. URL http://www.escholarship.org/uc/item/3mw325br

Nash, R. (1967) Wilderness and the American Mind. New Haven, CT, USA: Yale University Press.

Neumann, R. (1998) Imposing Wilderness. Berkeley, CA, USA: University of California Press.

Neumann, R. (2001) Africa's 'last wilderness' reordering space for political and economic control in colonial Tanzania. Africa 71: 641-665.

Neumann, R. (2002) The postwar conservation boom in British Colonial Africa. Environmental History 7(1): 22-47.

Neumann, R. (2004) Moral and discursive geographies in the war for biodiversity in Africa. Political Geography 23: 813-837.

Ostrom, E. (1990) Governing the Commons: The Evolution of Institutions for Collective Action. Cambridge, UK: Cambridge University Press.

Pagiola, S., Arcenas, A. \& Platais, G. (2005) Can payments for environmental services help reduce poverty? An exploration of the issues and the evidence to date from Latin America. World Development 33(2): 237-253.

Peluso, N. (1993) Coercing conservation? The politics of state resource control. Global Environmental Change 3: 199-218.

Pollini, J. (2007) Slash-and-burn cultivation and deforestation in the Malagasy rain forests: representations and realities. Ph.D. dissertation, Cornell University, Ithaca, USA.

Quarles van Ufford, P., Kumar, A. \& Mosse, D. (2003) Interventions in development: towards a new moral understanding of our experiences and an agenda for the future. In: A Moral Critique of Development: In Search of Global Responsibilities, ed. P. Quarles van Ufford \& A. Giri, pp. 3-43. London, UK: Routledge.
Ryan, J. \& Robinson, M. (1990) Implementing participatory action research in the Canadian north: a case study of the Gwich'n in language and cultural project. Culture 10: 57-71.

Schroeder, R. (1999) Community, forestry and conditionality in the Gambia. Africa 69: 1-22.

Shrestha, K.K. \& McManus, P. (2007) The embeddedness of community forestry in Nepal. Fournal of Smallscale Forestry $\mathbf{6}$ : 273-290.

Shrestha, K. K. \& McManus, P. (2008) The politics of community participation in natural resource management: lessons from community forestry in Nepal. Australian Forestry 71: 135-146.

Simpson, L. (2001) Aboriginal peoples and knowledge: decolonizing our processes. The Canadian Fournal of Native Studies 21: 137-148.

Soule, M. \& Lease, G. (1995) Reinventing Nature? Responses to Postmodernism. Washington, DC, USA: Island Press.

Stevens, S. (1997) Conservation through Cultural Survival: Indigenous Peoples and Protected Areas. Washington, DC, USA: Island Press.

Stocks, A. (1996) The Bosawas Natural Reserve and the Mayangna of Nicaragua. In Traditional Peoples and Biodiversity Conservation in Large Tropical Landscapes, ed. K. Redford \& J. Mansour, pp. 1-30. Washington, DC, USA: America Verde Publications.

Stocks, A. (2003) Mapping dreams in Nicaragua's Bosawas Reserve. Human Organization 62: 344-356.

Stocks, A., McMahan, B. \& Taber, P. (2007) Indigenous, colonist and government impacts on Nicaragua's Bosawas Reserve. Conservation Biology 21: 1495-1505.

Toillier, A., Lardon, S. \& Hervé, D. (2008) An environmental governance support tool: community-based forest management contracts (Madagascar). International fournal of Sustainable Development 11: 187-205.

Vitug, M. (2000) Forest policy and national politics. In: Forest Policy and Politics in the Philippines. The Dynamic of Participatory Conservation. ed. P. Utting, pp. 11-40. Quezon City, Philippines: Anteneo De Manila University Press.

WCED (1987) Our Common Future. Oxford, UK: Oxford University Press.

Weber, J. (1995) L'occupation humaine des aires protégées à Madagascar: diagnostic et éléments pour une gestion viable. Natures Sciences Sociétés 3: 157-64.

West, P. (2007) Conservation is our Government. The Politics of Ecology in Papua Nem Guinea. Durham, NC, USA: Duke University Press.

West, P. \& Brechin, S. (1991) Resident Peoples and National Parks: Social Dilemmas and Strategies in International Conservation. Tuscon, AZ, USA: University of Arizona Press.

Western, D. \& Wright, M. (1994) Natural Connections: Perspectives in Community-based Conservation. Washington, DC, USA: Island Press.

Wilshusen, P., Brechin, S., Fortwangler, C. \& West, P. (2002) Reinventing a square wheel: critique of a resurgent 'protection paradigm' in international biodiversity conservation. Society and Natural Resources 15: 17-40.

Wittayapak, C. \& Dearden, P. (1999) Decision-making arrangements in community-based watershed management in northern Thailand. Society and Natural Resources 12(7): 673-691. 